\title{
The growth of the banded carpet shell (Paphia rhomboïdes) in a contrasted region, the English Channel (Western Europe): A modelling study
}

\author{
Marie Savina $^{1^{*}}$ and Alain Ménesguen ${ }^{2}$
}

1 CSIRO Marine Research, Castray Esplanade, HOBART TAS 7000, Australia

2 Centre IFREMER de BREST BP 70, 29280 PLOUZANE, France

*: Corresponding author : marie@niyelopell.com

\begin{abstract}
:
Paphia rhomboïdes is an infaunal filter-feeding bivalve, particularly widespread and abundant in the English Channel. In order to investigate the influence of the growth-related post-settlement processes on its distribution, a spatial growth model was developed and linked to an existing ecological model of the English Channel. This model was partially parameterized on the basis of a specific ecophysiological experimental study, and calibrated with growth data collected in the "Golfe NormandBreton" (GNB), a region of the English Channel. Compared to the actual distribution of $P$. rhomboïdes, the results suggest a strong influence of the growth-related processes on the distribution of the species: particularly, the extremely low growth obtained with the model in the Western Channel can explain the almost complete absence of the species in this area.
\end{abstract}

Keywords: Paphia rhomboïdes; English Channel; Growth model; Ecophysiology; Meroplanktonic invertebrates distribution 


\section{Introduction}

Diversity and abundance of the benthic fauna in the English Channel has favoured the development of fisheries, particularly those of shellfish: scallop, warty venus, common cockle, dog cockle, banded carpet shell, surf clam (Berthou, 1983; Lemoine et al., 1988; Fifas, 1991; Noël et al., 1995). It has also attracted the interest of scientists: large scientific programs were carried out in the seventies (Holme, 1966; Cabioch, 1968; Cabioch and Glaçon, 1975 and 1977; Gentil, 1976; Cabioch et al., 1977; Retière, 1979) to study benthos distribution in the area, as well as the environmental factors controlling it.

Among the main listed bivalves, the banded carpet shell (Paphia rhomboïdes) -a subtidal infaunal filter-feeding species- is particularly widespread in the English Channel and in the central part, i.e., the "Golfe Normand-Breton", where, in terms of biomass, it is one of the most abundant species (Holme, 1966; Retière, 1979; Blanchard, 1982; Blanchard et al., 1983). Because it is a targeted species (Berthou, 1985, 1987 and 1989; Noël et al. 1995) and extensive scientific data have been collected describing its distribution, biology and ecology (Holme, 1966; Cabioch, 1968; Lucas, 1969; Chassé and Glémarec, 1973; Gentil, 1976; Glémarec and Bouron, 1978; Retière, 1979; Blanchard, 1982; Blanchard et al., 1983 and 1986 a and b; Morvan, 1987; Morin 1998), this species is of particular interest for studying the distribution of meroplanktonic invertebrates in the English Channel.

The importance of post-recruitment processes in the spatial distribution of the benthicmeroplanktonic bivalves is generally accepted (Thouzeau, 1989; Young et al., 1998; Bhaud, 2000). Thus, successful larval transport by currents, and even successful larval settlement on the substratum, are not necessarily followed by the continuation of the life cycle and the development of adulthood (Bhaud, 2000).

Post-recruitment structuring processes could be classified into two groups: 
(1) Direct mortality factors, such as predation, human harvesting, or indirect mortality factors such as mechanical disturbance, due to turbulence or dredging, which can be responsible for an enhanced predation;

(2) Parameters which influence the physiological state and growth of animals (temperature, food, inorganic seston, turbulence). These may influence the bivalve mortality rate, directly (physiological distress) or indirectly (slow growth, smaller individuals being supposed to be more vulnerable than bigger ones), and also influence the fertility of bivalves since their reproductive investment depends on their size and growing conditions (Héral and DeslousPaoli, 1983; Urrutia et al., 1999; Pouvreau et al., 2000 b).

In the present study, we focused on the latter group of post-recruitment structuring processes with an ecophysiological modelling approach.

Since the beginning of the 1990s, ecophysiological (or growth) models of filter-feeding molluscs have become more numerous (Bensch et al., 1991; Raillard et al., 1993; Barillé, 1996; Kobayashi et al., 1997; Campbell and Newell, 1998; Grant and Bacher, 1998; Scholten and Smaal, 1998; Pouvreau et al., 2000 a; Solidoro et al., 2000; Cardoso et al., 2001; Ren and Ross, 2001; Hawkins et al., 2002). The objectives are usually to improve the aquaculture techniques and management through a better understanding of processes which drive the growth of the different cultivated species. To our knowledge, growth models have never been used to investigate the spatial distribution of filter-feeding molluscs. In addition, a review of these previously cited models bring the following observations:

(1) The great majority of published models are only used in a given environment with a limited extension (trophic and climatic characteristics). Only a few teams have tried to transpose their model to various regions (Grant et Bacher, 1998; Scholten and Smaal, 1998; Ren and Ross, 2001).

(2) Individual growth is generally simulated during periods which range from 9 months (Kobayashi et al., 1997; Grant and Bacher, 1998) to 3 years (Solidoro et al., 2000), i.e., during 
only a part of their life. Only a few studies considered the whole life of the studied bivalve (e.g., Cardoso et al., 2001).

(3) Most models have focussed on epibenthic species, and furthermore these species are often located within the water column (on "tables" or as suspended culture on ropes hung from longlines or rafts). Interest for infauna species is more recent (Solidoro et al., 2000; Cardoso et al., 2001).

The complexity of these models depends on their objectives and the available data, but they are all based on the following equation:

$$
\frac{d W}{d t}=\text { nutrition }(t)-\text { respiration }(t)-\text { reproduction }(t)
$$

where W is the global soft bodies weight of the considered shellfish (either fresh or dry or ash free dry)

The soft bodies weight can be considered as a global state variable (Grant and Bacher, 1998;

Solidoro et al., 2000), or several compartments can be considered, such as shell (inorganic and organic content), reserve compartments, gonad, which implies the formulation of transfer processes between these compartments (e.g., Kobayashi et al., 1997; Cardoso et al., 2001; Hawkins et al., 2002). More detailed models consider not only the weight of the different flesh compartments but also their carbohydrates, lipid and protein content (e.g., Barillé, 1996).

In the present study, a relatively simple growth model is designed for $P$. rhomboïdes, considering their whole benthic life. This model is first tested and used in the Golfe NormandBreton region, where we collected data, and then extended to the whole English Channel to investigate the potential importance of the ecophysiological processes in the distribution of the species. 


\section{Material and method}

\subsection{The background model}

A physical box-model has been developed for the English Channel (Ménesguen and Hoch, 1997) and coupled to a biogeochemical model (Hoch, 1998), using the ELISE software (Ménesguen, 1991). The physical sub-model of the Channel is divided into 71 boxes or compartments (figure 1) with water flows between them calculated automatically from the tidal residual circulation, and a 2-layer, vertical thermohaline model, linked with the horizontal circulation scheme, to simulate thermal or haline stratification.

The biological sub-model explicitly takes into account the nitrogen, phosphorus and silicon biogeochemical cycles and converts some biological variables into carbon. The pelagic system is described by three phytoplanktonic compartments, and by considering the microbial food web (Hoch, 1998).

\subsection{The growth model}

\subsubsection{Growth data}

2.2.1.1 Life growth curves

Individuals of $P$. rhomboïdes were collected in the different areas of the "Golfe NormandBreton" (GNB, figure 1) during four cruises: BENTHOMONT I and II (April 2002), BIVALVES I and II (May 2002) (Savina, 2004). The number of individuals obtained in each compartment depended on the sampling effort and density of the species (table 1).

All animals were aged, by counting the annual growth bands on their shell (Berthou et al., 1986) and shell length measured to the nearest $\mathrm{mm}$. In three compartments of the GNB, randomly selected animals were weighed. They were washed gently with freshwater; and the soft bodies were separated from the shell, and weighted to the nearest $\mathrm{mg}$, after drying at $80^{\circ} \mathrm{C}$ for $24 \mathrm{~h}$. and combusting at $450^{\circ} \mathrm{C}$ for $4 \mathrm{~h}$. The relationship (figure 2) between shell length and ash free dry weight (AFDW) was used to convert the shell length of all sampled 
bivalves into AFDW of soft bodies (assuming that the data obtained during the two cruises and in the different compartments can be pooled together). For each compartment, these data were used to build a growth curve (AFDW vs. age), assuming that the obtained "instantaneous" growth curves is similar to the "historic" ones (i.e., obtained by measuring the growth of one cohort during several years). For each age, the mean AFDW values are assumed to correspond to the weight on the 29/04, average sampling date.

\subsubsection{Annual growth curves}

A shellfish factory (CELTARMOR) located in the "Baie de Saint-Brieuc" (coast of compartment A, figure 1) produces shelled and frozen banded carpet shells. Only animals fished in Compartment A are treated in this factory. A mean production output is calculated every month which corresponds to the ratio: total weight of frozen soft bodies/total fresh weight (shell and soft bodies, Brezellec personal communication, 2002). In the same manner, Morvan (1987) calculated an individual condition index of $P$. rhombö̈des from a station located in the compartment E (figure 1) over a two year period, which corresponds to the ratio dry weight of soft bodies/total dry weight (soft bodies and shell).

Assuming that the shell weight does not vary too much during a year, these indices give fairly good indications about the intra-annual soft-bodies weight variations of the shellfish.

\subsubsection{Ecophysiological experiments}

An ecophysiological study of $P$. rhomboïdes was conducted during September-October 2002 in the IFREMER station of Argenton, to obtain the mean values of clearance, absorption and respiration rates of this species. These parameters were studied in the mean ranges of temperature and chlorophyll concentrations that can be found in the GNB; only the temperature minimum condition was not applied because of technical problems. All these results are available in Savina and Pouvreau (2004). 


\subsubsection{The growth model}

The ash free dry weight (AFDW) of soft body (mg) was the only state variable finally considered. Equations of the growth model and parameter values are shown respectively in

tables 2 and $\mathbf{3}$. A conceptual diagram is also presented in figure 3.

Ecophysiological experiments showed that the filtration rate of $P$. rhomboïdes is mainly controlled by the particulate organic matter (POM) concentration in the investigated range of temperature (Savina and Pouvreau, 2004). The parameters of the filtration rate equation (table 2 (1)), obtained with a phytoplankton cocktail (the concentration of which was expressed in $\mu \mathrm{g} \mathrm{l}^{-1} \mathrm{chl}$. a), were converted in order to use this equation with a food concentration expressed in $\mathrm{mg} \mathrm{l}^{-1}$ dry weight of POM (table 4). It was assumed that the measured clearance rate was equivalent to the filtration rate (see Savina and Pouvreau, 2004).

Due to the limited range of temperature investigated in our experiments and to its demonstrated influence on physiological rate, the influence of temperature on the filtration rate was considered in the model, using the formulation suggested in Goulletquer et al (1989). Food selection processes were not considered in the model. The ingestion rate was calculated directly with the filtration rate and the food concentration in the filtered sea water (table 2 (2)). In the same manner, the excretion processes were neglected, and a simple absorption rate (instead of an assimilation rate) was used for the Scope for Growth (ie: the energy available to grow, once the respiration and reproduction losses have been deduced from the gain due to nutrition) calculations. To reflect the limited capacity of an organism to produce biomass (ie: to create tissues) even in optimal trophic conditions, a maximum daily absorption rate was introduced (table 2 (3)). Metabolic requirements can be divided into two categories: the basal metabolic rate which represents the metabolic rate of a non-feeding animal, and the routine metabolic rate, which include the additional requirements associated with e.g., feeding and digestion (Bayne et al., 1989). The respiration rate is also influenced by environmental parameters, mainly temperature (Winter, 1979; Shumway and Koehn, 1982; Bernard, 1983; Riva and Massé, 1983; Bodoy et al., 1986; Laing et al., 1987; Le Gall and Raillard, 1988; 
Goulletquer et al., 1989). Though we did not find any significant influence of the temperature on the respiration rate of $P$. rhomboïdes in the investigated range of temperature, again we found more reasonable to consider it. The respiration rate measurements of $P$. rhomboïdes (Savina and Pouvreau, 2004) were therefore re-considered, as a function of temperature and absorption rate (which represents an indicator of the feeding activity; Bayne et al., 1989). Here also, we considered the formulation suggested in Goulletquer et al. (1989) (table 2 (4)). As only the global AFDW of soft bodies is considered in this model, reproduction consists of a simple weight loss during the presumed spawning period (table 2 (5)). The reproductive effort (proportion of SFG devoted to the reproduction) of bivalve species is considered as increasing with age or with the body weight (Héral et Deslous-Paoli, 1983; Urrutia et al., 1999; Pouvreau et al., 2000 b). Here, the weight loss corresponding to the spawn is calculated from the reached weight at the beginning of the spawning period, and the reproductive effort is an asymptotic function based on Pouvreau et al. (2000 b).

Considering the numerous results of the measurements done on several bivalve species (review in Pouvreau et al., 1999 and Savina and Pouvreau, 2004 for example) and the geometric considerations about the influence of size of an organism on its physiological rate (West et al., 1997; Kooijman, 2000), the allometric coefficients were set to $2 / 3$ for the filtration rate, and 3/4 for the respiration rate.

\subsubsection{Environmental data}

Food and temperature data used in the growth model were obtained with the biogeochemical model of Hoch (1998). Two types of food were considered among the different pelagic state variables: diatoms and detrital particulate organic matter. They were expressed in the biogeochemical model in $\mu \mathrm{g} \mathrm{l}^{-1} \mathrm{~N}$ and $\mu \mathrm{g} \mathrm{l}^{-1} \mathrm{C}$ respectively; and were converted into $\mathrm{mg}$ dry matter of POM (table 5). We assumed that the filtration and ingestion behaviour of $P$. rhomboïdes is the same with natural organic seston than it has been with pure phytoplankton mixture during the experiments (on the basis of which the relationship food-filtration rate was established, Savina and Pouvreau, 2004). 

194 from 1999 to 2001) with the OC5 algorhithm (Gohin et al., 2002) allowed the calculation of 195 an annual average concentration of suspended inorganic matter (or suspended sediment) in 196 each compartment. Considering the important vertical mixing in the GNB, these averages 197 were considered as correct indicators of the sediment load in bottom water. 


\section{Results}

\subsection{The growth of $P$. rhomboïdes in the GNB}

The examination of the environmental parameters (figure 4) distinguishes two zones in the Golfe Normand-Breton (GNB): (1) an "oceanic" zone with clear, relatively poor resources water, and a weak thermal seasonal contrast (compartments A, B, C and D); and (2) a "coastal" zone with higher concentrations of food and suspended sediment and a higher seasonal contrast (compartments E, F, G and H).

The growth model was used first without considering suspended sediment concentration influence on the total absorption rate. The absorption efficiency of detrital particulate organic matter and the reproduction parameters were calibrated in the region providing the most complete data set, i.e., the compartment A (Bay of Saint-Brieuc). The agreement between the observed and predicted AFDW is correct for the compartment A, B, C and D (figure 5), but the model largely overestimates the growth in the other compartments (E, F, G and $\mathrm{H})$.

The suspended sediment concentrations in the compartments E, F, G and $\mathrm{H}$ (figure 4) are significantly higher than in the first set of compartments (where the model gives good results). Therefore, we tried to improve the model considering the influence of this parameter on the nutrition processes in a simple manner. For each of the 4 compartments concerned (E, $\mathrm{F}, \mathrm{G}$ and $\mathrm{H})$, a correction factor of the total absorption efficiency $\left(\mathrm{F}_{\text {pim }}\right)$ was calibrated, in order to obtain the best fit between the observed and predicted AFDW.

Then the values found for $\mathrm{F}_{\mathrm{pim}}$ for each compartment were plotted as a function of the suspended sediment concentration (figure 6). A linear relationship clearly appears $\left(\mathrm{R}^{2}=74 \%\right)$, which confirms that this environmental parameter is important to be considered. Thus, this correction factor was included into the model as it is shown in table 2(3). The results of this new version of the model are shown in figure $\mathbf{7}$ and $\mathbf{5}$. The agreement between the observed and predicted AFDW is now correct for all the compartments (except for some points in the compartments $\mathrm{E}$ and $\mathrm{F}$, but there the data could be doubtful). 
Assuming that the shell weight is constant, the mean production output of the shellfish factory as well as the condition index both described in the materials and methods section give a good idea of the change in the mean AFDW of an animal. We compared these indices to the predicted annual change in the ASDW of a 5 years old animal, with a shell growth assumed to be negligible (figure 8). In the compartment A, the observed and predicted periods of both maximum weight and decrease of the weight at the end of summer coincide. However, the model predicts a later and shorter period of growth than the observed one. In compartment E, the predicted and observed annual evolutions of the animal weight are similar, but there is a time lag about 80 days.

Figure 9 compared to figure 4 shows that the simulated growth of $P$. rhomboïdes in the different compartments is the result of the antagonistic actions of food and suspended sediment concentrations. The higher growth is observed in the "continental" compartments G, $\mathrm{H}$ and $\mathrm{E}$ but also in the "oceanic" compartment $\mathrm{A}$, where the absence of suspended sediment compensates the relatively poor food resources. Nevertheless, the lowest growth corresponds to poor "oceanic" compartment (B and C).

\subsection{Results of the growth model in the English Channel}

Six categories of compartments can be considered (figure 10): (1) a first one where the AFDW of soft bodies goes to 0 very rapidly i.e., where the growth of juveniles is not possible; (2) a second one where the AFDW of soft bodies is maintained between 5 and $200 \mathrm{mg}$ without any real growth; and (3) finally 4 regions where growth is possible.

Figures 10 and $\mathbf{1 1}$ show the relationship between the growth capabilities of the species and its real occurrence (dredging data from Cabioch, personal communication, 2002). The proportion of boxes where $P$. rhomboïdes is present clearly increases from the first to the last growth group.

The differences of growth between the two annual cohorts are of variable importance depending on the regions (and therefore on the growth capabilities of the individuals), but vanish everywhere for 7 years (or more) old individuals (figure 10). 
252

253

\subsubsection{The growth model development}

This model was built with a global mechanistic approach; the main ecophysiological processes were considered (nutrition, digestion, respiration, reproduction), as well as the main environmental parameters known to have an influence on these processes in the marine subtidal environment (temperature, food and inorganic seston concentrations). Some of the processes formulation and parameter values were based on measurements (Savina and Pouvreau, 2004) or literature data. Nevertheless, detailed information and parameter values were not available for all processes, and it did not appear necessary to design a too much detailed model for this study because of the considered spatial scale, and of the availability of the data.

The feeding behaviour and digestion efficiency of different infaunal bivalve species facing to different qualities and quantities of seston (e.g., organic/inorganic matter proportion, organic matter concentration, living/non living organic matter) have been intensively studied (Widdows, 1978; Winter, 1979; Fiala-Medioni et al., 1983; Bayne et al., 1989; Goulletquer et al., 1989; Barillé, 1996; Barillé et al., 1997; Defossez and Hawkins, 1997; Dolmer, 2000; Riisgard et al., 2003), most concerned with much more turbid and productive environments than most of the English Channel; while one of the main results of the cited studies is that the feeding behaviour and digestion efficiency of bivalves highly depend on the species and on the environmental conditions in their usual habitat. No specific study about $P$. rhomboïdes behaviour has occurred. Moreover, the spatial resolution of our model and the food and turbidity dataset that we used did not allow us to consider such detailed processes (food selection, pseudo-faeces production, variations in digestion time and/or efficiency). As a consequence, we considered the nutrition processes in a simple manner, and only added a level of regulation (influence of the inorganic matter concentration) on the basis of the results obtained with the previous version. 
Although they were not necessary to obtain satisfying results in the GNB, some processes were included in the model for application to the whole English Channel, in order to address the broader range of environmental parameter values:

(1) the regulation of the filtration rate by temperature, which is more likely to be the limiting factor for nutrition in rich environments such as estuaries, while food concentration is clearly the limiting factor in the GNB.

(2) the introduction of a daily growth rate limitation, which reflects the limited capacity of an organism to produce biomass (ie: to create tissues) even in optimal trophic conditions.

These two processes were formulated and parameterised in order not to affect the results in the GNB.

\subsubsection{The growth model results and its application on the distribution of $P$. rhomboïdes}

The obtained model simulates a realistic behaviour of shellfish weight: the alternation of weight gain (in summer) and loss (in winter) year after year, with a positive annual budget during the first period and a balanced one after (examples of experimental data in the following papers: Bacher and Goulletquer, 1989; Scholten and Smaal, 1998; Urrutia et al, 1999; Ren and Ross, 2001).

Unfortunately, we do not have any data about the growth of this species outside of the GNB. Given the demonstrated plasticity of molluscs (Hadfield and Strathmann, 1996; Kooijman, 2000), we consider our results in the whole English Channel as reasonable. However, we expected that the high turbidity in the "Bay of Seine" would have prevented such an important growth of $P$. rhomboïdes (black area in figure 10). The turbidity data that we used, the calibrated function absorption rate-turbidity and the simple function of growth limitation are probably too simple to allow a real investigation of the growth in really turbid and rich environments such as the "Bay of Seine".

In spite of this remaining weakness, the obtained results provide a fruitful explanation to the observed distribution of the species in the Channel: 
(1) Growth is impossible in the $1^{\text {st }}$ category (figure 10) and therefore survival too, whatever the input of larvae and their settlement conditions.

(2) In the $2^{\text {nd }}$ category, the initial weight is maintained, but without proper growth. The mortality rate of the eventually settled individuals is therefore considered to be very important, and if there are survivors, they do not reach a weight sufficient to enable reproduction. The population can therefore be maintained only by the input of allochtonous larvae. This corresponds to the concept of sterile population proposed by Bhaud (2000).

(3) Our third and fourth categories of populations are distinguished by their growth rates during the first 4 or 5 years: it can influence the mortality rate, considering that the smaller individuals are more vulnerable (predation, mechanical disturbance, lack of metabolic reserves ...). It can also influence the age of first maturity, since the energetic investment in the reproduction depends on the size of the bivalve (Héral et Deslous-Paoli, 1983; Urrutia et al., 1999; Pouvreau et al., 2000 b). These groups are also distinguished by the adult weight that they finally reach, which have consequences on the reproduction too.

(4) The simulated differences of growth between the two annual cohorts during the growth period are consistent with the observations made in the "Golfe Normand-Breton" (Blanchard et al, 1986 a). During the first year, the first recruited cohort has more time to grow before the winter period than the second one, which increases its survival chances (Thouzeau and Lehay, 1988); the first cohorts keep an advantage during a few years.

The proportion of boxes where $P$. rhomboïdes is present clearly increases from the first to the next-to-last growth group (figure 10-central map; the last group is not considered due to the problems detailed before), which suggests the importance - at this scale - of the postrecruitment growth-related processes in the distribution of this species, through action on survival rate and fecundity. Particularly, the extremely low growth obtained in the Western Channel can explain the almost complete absence of the species in this area.

Contrasting with the high growth potential provided by our growth model, and hence the favourable conditions of population settlement, $P$. rhomboïdes is actually absent from the 
"Bay of Seine" (black area in figure 10). This can be due to growth-related mortality in 331 relation with the high turbidity, and in this case, our model failed to explain it, but it could 332 also be due to other factors not considered here (settlement of post-larvae in instable muddy 333 substrates, gill clogging, high predation or competition with more adapted species ....). In all useful comments and corrections. 


\section{References}

Aminot, A., Guillaud, J.F., Kerouel, R., 1997. La Baie de Seine : hydrologie, nutriments et chlorophylle (1978-1994). Repère Océan, 14. Editions IFREMER, Brest, 21pp.

Bacher, C., and Goulletquer, P., 1989. Comparaison des relations trophiques de Ruditapes philippinarum en milieux estuarien et océanique à partir d'un modèle de croissance. Can. J. Fish. Aquat. Sci. 46, 1160-1170.

Barillé, A.L., 1996. Contribution à l'étude des potentialités conchylicoles du Pertuis Breton. Thèse de doctorat de l'université d'Aix-Marseille II, France, 250 pp.

Barillé, L., Prou, J., Héral, M., Razet, D., 1997. Effects of high natural seston concentrations on the feeding, selection, and absorption of the oyster Crassostrea gigas (Thunberg). J. Exp. Mar. Biol. Ecol. 212, 149-172.

Bayne, B.L., Hawkins, A.J.S., Navarro, E., Iglesias, I.P., 1989. Effects of seston concentration on feeding, digestion and growth in the mussel Mytilus edulis. Mar. Ecol. Prog. Ser. 55, 4754.

Bensch, A., Bacher, C., Baud, J.P., Martin, J.L., 1991. Modélisation de la croissance de Ruditapes philippinarum dans un système expérimental. Haliotis 13, 71-82.

Bernard, F.R., 1983. Physiology and the mariculture of some north-eastern Pacific bivalve molluscs. Can. Spec. Publ. Fish. Aquat. Sci. 63, 1-24.

Berthou, P., 1983. Contribution à l'étude du stock de praires (Venus verrucosa L.) du golfe Normand-Breton. Thèse de doctorat de l'université de Bretagne occidentale, France, 157 pp. Berthou, P., 1985. Etude des praires et des bivalves associés en Bretagne nord. Rapport intermédiaire CRUSCO, $10 \mathrm{pp}$.

Berthou, P., 1987. Note interne concernant la mise en valeur des bivalves autres que les pectinidés, 27 pp.

Berthou, P., 1989. Note interne sur l'exploitation des petits bivalves, 27 pp. 
Berthou, P., Blanchard, M., Noël, P., Vergnaud-Grazzini, C., 1986. L'analyse des isotopes stables de la coquille appliquée à la détermination de l'âge de quatre bivalves du Golfe Normand-Breton (Manche occidentale). ICES COUNCIL MEETING 1986 (collected papers)., ICES, COPENHAGEN, DENMARK, 13 pp.

Bhaud, M., 2000. Two contradictory elements determine invertebrate recruitment: dispersion of larvae and spatial restrictions on adults. Ocean. Acta 23, 409-422.

Blanchard, M., 1982. Peuplement des sables grossiers. In: Etude écologique d'avant-projet du site marémoteur du golfe Normand-Breton: Le benthos subtidal. Rapport final EDF/CNEXO/MNHN, Brest, pp 35-67.

Blanchard, M., Chardy, P., Dreves, L., Guennegan, Y., 1983. Les Bivalves. In: Etude écologique du site Cotentin centre. Volume 3: Le subtidal. Rapport CNEXO/EDF, Brest, 150 pp.

Blanchard, M., Morvan, C., Quiniou, F., 1986a. Dynamique de population de la palourde rose Tapes rhombö̈des (Pennant, 1977) dans le golfe Normand-Breton. Haliotis 15, 91-101.

Blanchard, M., Piriou, J.Y., Berthou, P., Morvan, C., Quiniou, F., Chardy, P., Retière, C., Heliez, A., Le Calvez, J.C., 1986 b. Le benthos subtidal. Tome 3 de l'Etude Régionale Intégrée du Golfe Normand-Breton. Rapport IFREMER-DERO-86.27-EL, Brest, 100 pp.

Bodoy, A., Riva, A., Maitre-Allain, T., 1986. A comparison of oxygen consumption in the carpet-shell clam, Ruditapes decussatus (L.) and the manila clam $R$. philippinarum as a function of temperature. Vie et milieu 36 (3), 83-89.

Brown, M.R., 1991. The amino-acid and sugar composition of 16 species of microalgae used in mariculture. J. Exp. Mar. Biol. Ecol. 145, 79-99.

Cabioch, L., 1968. Contribution à la connaissance des peuplements benthiques de la Manche Occidentale. Cah Biol Mar IX (5), 720 pp.

Cabioch, L., Gentil, F., Glaçon, R., Retière, C., 1977. Le macrobenthos des fonds meubles de la Manche : Distribution générale et écologie. In: Keegan BF, Ceidigh PO, Boaden PJS (eds) 
Biology of benthic organisms. 11 th European Symposium on Marine Biology, Galway, October 1976. Pergamon Press Oxford, UK, 115-128.

Cabioch, L. and Glaçon, R., 1975. Distribution des peuplements benthiques en Manche Orientale, de la Baie de Somme au Pas-de-Calais. C. R. Acad. Sc. Paris 280 D, 491-494.

Cabioch, L. and Glaçon, R., 1977. Distribution des peuplements benthiques en Manche Orientale, du Cap d'Antifer a la Baie de Somme. C. R. Acad. Sc. Paris 285 D, 209-212.

Campbell, D.E. and Newell, C.R., 1998. MUSMOD, a production model for bottom culture of the blue mussel, Mytilus edulis L. J. Exp. Mar. Biol. Ecol. 219, 171-203.

Cardoso, J.F.M.F., Van der Meer, J., Van der Veer, H.W., 2001. Interspecies comparison of energy flow in some North Atlantic bivalve species by means of dynamic energy budgets. ICES CM 2001/J: 43.

Chassé, C. and Glémarec, M., 1973. Les bancs de Venerupis rhomboïdes des Glénans. Fac. Sci. Brest. Rapport contrat CNEXO 72/527.

Defossez, J.M. and Hawkins, A.J.S., 1997. Selective feeding in shellfish: size-dependent rejection of large particles within pseudofaeces from Mytilus edulis, Ruditapes philippinarum and Tapes decussatus. Mar. Biol. 129, 139-147.

Dolmer, P., 2000. Feeding activity of mussels Mytilus edulis related to near-bed currents and phytoplankton biomass. J. Sea Res. 44, 221-231.

Eppley, R.W., Rogers, J.B., Mc Arthy, J.J., Sournia, A., 1971. Light/Dark periodicity of nitrogen assimilation of the marine phytoplankter Skeletonema costatum and Coccolithothus huxleyi in N limitation chemostat culture. J. Phycol. 7, 150-154.

Fiala-Medioni, A., Copello, M., Colomines, J.C., 1983. Relations trophiques entre huîtres et milieu; influence de la concentration et de la taille des particules. Bases biologiques de l'aquaculture, Montpellier, 1983. IFREMER Actes de colloques 1, 63-74.

Fifas, S., 1991. Analyse et modélisation des paramètres d'exploitation du stock de coquilles Saint-Jacques (Pecten maximus, L.) en Baie de Saint-Brieuc (Manche Ouest, France). Thèse de l'université de Bretagne Occidentale, France, 300 pp. 
Gentil, F., 1976. Distribution des peuplements benthiques en baie de Seine. Thèse de doctorat de l'université de Paris VI, France, 250 pp.

Glémarec, M. and Bouron, D., 1978. Evolution de la maturité sexuelle chez six espèces de bivalves des Glénan. Haliotis 9(1), 45-48.

Gohin, F., Druon, J.N., Lampert, L., 2002. A five channel chlorophyll concentration algorithm applied to SeaWiFS data processed by SeaDAS in coastal waters. Int. J. Remote Sensing 23(8),1639-1661.

Goulletquer, P., Héral, M., Deslous-Paoli, J.M., Prou, J., Garnier, J., Razet, D., Boromthanarat, W., 1989. Ecophysiologie et bilan énergétique de la palourde japonaise d'élevage Ruditapes philippinarum. J. Exp. Mar. Biol. Ecol. 132, 85-10.

Grant, J. and Bacher, C., 1998. Comparative models of mussel bioenergetics and their validation at field culture sites. J. Exp. Mar. Biol. Ecol. 219, 21-44.

Hadfield, M.G. and Strathmann, M.F., 1996. Variability, flexibility and plasticity in life histories of marine invertebrates. Oceanol. Acta 19 (3-4), 323-334.

Hawkins, A.J.S., Duarte, P., Fang, J.G., Pascoe, P.L., Zhang, J.H., Zhang, X.L., Zhu, M.Y., 2002. A functional model of responsive suspension-feeding and growth in bivalve shell fish, configured and validated for the scallop Chlamys farreri during culture in China. J. Exp. Mar. Biol. Ecol. 281, 13-40.

Héral, M. and Deslous-Paoli, J.M., 1983. Energetic value of the tissue of the oyster Crassostrea gigas estimated by microcalorimetric measures and by biochemical evaluation. Oceanol. Acta 6 (2), 193-199.

Hoch, T., 1998. Modélisation du réseau trophique pélagique et de la production primaire en Manche. Oceanol. Acta 21, 871-885.

Holme, N.A., 1966. The bottom fauna of the English Channel. Part II. J. Mar. Biol. Assoc. U. K. 46, 401-493.

Kobayashi, M., Hofmann, E.E., Powell, E.N., Klinck, J.M., Kusaka, K., 1997. A population dynamics model for the Japanese oyster, Crassostrea gigas. Aquaculture 149, 285-321. 
Kooijman, S.A.L.M., 2000. Dynamic Energy and Mass Budgets in Biological Systems, $2^{\text {nd }}$ Edition. Cambridge University Press, 424 pp.

Laing, I., Utting, S.D., Lilada, R.W.S., 1987. Interactive effect of diet and temperature on the growth of juvenile clams. J. Exp. Mar. Biol. Ecol. 113, 23-38.

Le Gall, J.L. and Raillard, O., 1988. Influence of temperature on the physiology of the oyster Crassostrea gigas. Oceanis 14, 603-608.

Le Fêvre-Lehoërff, G., Erard-Le Denn, E., Arzul, G., 1993. Planktonic ecosystems in the channel. Trophic relations. Oceanol. Acta 16, 661-670.

Lemoine, M., Desprez, M., Ducrotoy, J.P., 1988. Exploitation des ressources en bivalves de la baie de Somme. Aménagement de la pêche à pied et état de la ressource en coques. Rapports scientifiques et techniques de l'IFREMER n8, $177 \mathrm{pp}$.

Lucas, A., 1969. Remarques sur l'hermaphrodisme juvénile de quelques veneridae (bivalvia). Malacologia 9 (1), 275-276.

Ménesguen, A., 1991. "ELISE”, an interactive software for modelling complex aquatic ecosystems. In: Arcilla A.S., Pastor M., zienkiewicz O.C. and Schrefler B.A. (eds) Computer Modelling in Ocean Engineering, 1991, Balkema, Rotterdam p 87-94.

Ménesguen, A. and Hoch, T., 1997. Modelling the biogeochemical cycles of elements limiting primary production in the English Channel. I. Role of thermohaline stratification. Mar. Ecol. Prog. Ser. 146, 173-188.

Morin, J., 1998. Prospection et évaluation des stocks de «petits bivalves » en Manche Est. Potentialités d'exploitation. Rapport interne DRV/RH/RST/98-13. 84 pp.

Morvan, C., 1987. Cycle de reproduction et fécondité de deux espèces de bivalves dans le golfe Normand-Breton. Thèse de doctorat de l'université de Bretagne occidentale, France, $138 \mathrm{pp}$.

Noël, P., Blanchard, M., Berthou, P., 1995. Cartographie et évaluation des principaux mollusques filtreurs du golfe Normand-Breton. Rapport interne DEL-DRV/RH /95.11., 31 pp. 
Pouvreau, S., Jonquières, G., Buestel, D., 1999. Filtration by the pearl oyster, Pinctada margaritifera, under conditions of low seston load and small particle size in a tropical lagoon. Aquaculture 176, 295-314.

Pouvreau, S., Bacher, C., Héral, M., 2000a. Ecophysiological model of growth and reproduction of the black pearl oyster, Pinctada margaritifera: potential applications for pearl farming in French Polynesia. Aquaculture 186, 117-144.

Pouvreau, S., Gangnery, A., Tiapari, J., Lagarde, F., Garnier, M., Bodoy, A., 2000 b. Gametogenic cycle and reproductive effort of the tropical blacklip pearl oyster, Pinctada margaritifera (Bivalvia: Pteriidae), cultivated in Takapoto atoll (French Polynesia). Aquat. Living Resour. 13 (1), 37-48.

Raillard, O., Deslous-Paoli, J.M., Héral, M., Razet, D., 1993. Modélisation du comportement nutritionnel de Crassostrea gigas dans le bassin de Marennes-Oléron. Oceanol. Acta 16, 7382.

Ren, J.S. and Ross, A.H., 2001. A dynamic energy budget model of the Pacific oyster Crassostrea gigas. Ecol. Model. 142, 105-120.

Retière, C., 1979. Contribution à la connaissance des peuplements benthiques du Golfe Normand-Breton. Thèse de doctorat de l'université de Rennes, France, 421 pp.

Riisgard, H.U., Kittner, C., Seerup, D.F., 2003. Regulation of opening state and filtration rate in filter-feeding bivalves (Cardium edule, Mytilus edulis, Mya arenaria) in response to law algal concentration. J. Exp. Mar. Biol. Ecol. 284, 105-127.

Riva, A. and Massé, H., 1983. Etude écophysiologique de quelques mollusques bivalves. In, IFREMER (eds) Bases biologiques de l'aquaculture, Act. Coll. Vol. 1, 45-62.

Savina, M., 2004. Modélisation écologique des populations de palourdes roses (Paphia rhomboïdes) et d'amandes de mer (Glycymeris glycymeris) en Manche. Thèse de doctorat de l'université d'Aix-Marseille II, France, 191 pp.

Savina, M. and Pouvreau, S., 2004. A comparative ecophysiological study of infaunal filterfeeding bivalves Paphia rhomboïdes and Glycymeris glycymeris. Aquaculture 239, 289-306. 
Scholten, H. and Smaal, A.C., 1998. Responses of Mytilus edulis L. to varying food concentrations: testing EMMY, an ecophysiological model. J. Exp. Mar. Biol. Ecol. 219, 217239.

Shumway, T.M. and Koehn, R.K., 1982. Oxygen consumption in the American oyster Crassostrea virginica. Mar. Ecol. Prog. Ser. 9, 59-68.

Soletchnik, P., Goulletquer, P., Héral, M., Razet, D., Geairon, P., 1996. Evaluation du bilan énergétique de l'huître creuse, Crassostrea gigas, en baie de Marennes-Oléron (France). Aquat. Living Resourc. 9, 65-73.

Solidoro, C., Pastres, R., Melaku Canu, D., Pellizzato, M., Rossi R., 2000. Modelling the growth of Tapes philippinarum in Northern Adriatic lagoons. Mar. Ecol. Prog. Ser. 199, 137148.

Thouzeau, G., 1989. Déterminisme du pré-recrutement de Pecten maximus (L.) en Baie de Saint-Brieuc. Thèse de doctorat de l'université de Bretagne Occidentale, France, 431 pp.

Thouzeau, G. and Lehay, D., 1988. Spatio-temporal variability of the distribution, growth and survival of Pecten maximus juveniles from the 1985 summer spawning, in the Bay of SaintBrieuc. Oceanol. Acta 11(3), 267-283.

Urrutia, M.B., Ibarrola, I., Iglesias, J.I.P., Navarro, E., 1999. Energetics of growth and reproduction in a high-tidal population of the clam Ruditapes decussatus from Urdaibai Estuary (Basque Country, N. Spain). J. Sea Res. 42, 35-48.

West, G.B., Brown, J.H., Enquist, B.J., 1997. A general model for the origin of allometric scaling laws in biology. Science 276, 122-126.

Widdows, J., 1978. Combined effects of body size, food concentration and season on the physiology of Mytilus edulis. J. Mar. Biol. Ass. U.K. 58, 109-124.

Winter, J.E., 1979. A critical review on some aspects of filter-feeding in lamellibranchiate bivalves. Haliotis 7, 71-87. 
526

527

528

529

530

531

532

533

534

535

536

537

538

539

540

541

542

543

544

545

546

547

548

549

550

551

552

Young, E.F., Bigg, G.R., Grant, A., Walker, P., Brown, J., 1998. A modelling study of environmental influences on bivalve settlement in the Wash, England. Mar. Ecol. Prog. Ser. $172,197-203$.

.

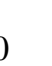

1

2

3

4

5

6

.

.




\section{Tables}

\begin{tabular}{llll}
\hline compartment & $\begin{array}{l}\text { total number of } \\
\text { sampled animal }\end{array}$ & age- shell length & $\begin{array}{l}\text { age-shell length- } \\
\text { AFDW }\end{array}$ \\
\hline A & 1595 & 1595 & 170 \\
B & 33 & 33 & 0 \\
C & 30 & 30 & 0 \\
D & 84 & 84 & 0 \\
E & 106 & 106 & 33 \\
F & 239 & 239 & 95 \\
G & 141 & 141 & 0 \\
H & 298 & 298 & 0 \\
\hline
\end{tabular}

559

Table 1: Number of individual measurements of Paphia rhomboïdes coming from the cruises BIVALVES and BENTHOMONT 2002. The third column gives the number of animals whose age and shell length are known, and the fourth one gives the number of animals whose age, shell length and AFDW of soft bodies are known. 
Table 2: Equations of the growth model
1) Filtration rate $\left(\mathrm{L} \mathrm{d}^{-1}\right)$ :
5) Weight loss due to reproduction $\left(\mathrm{mg} \mathrm{d}^{-1} \mathrm{DW}\right)$ :

$F R=f a \times e^{-\frac{f b}{P O M}} \times\left[f c \times(T-f d)^{f e} \times e^{f f \times(T-f d)}\right] \times\left(\frac{W}{1000}\right)^{b 1} \times 24$

if $t=t_{b}$ and $W \geq W_{\text {threshold }}$

2) Ingestion rate $\left(\mathrm{mg} \mathrm{d}^{-1} \mathrm{DW}\right)$ :

$I R_{\text {phy }}=F R \times P H Y$

$$
\text { reprod }=\frac{p a}{p b+p c \times e^{p d \times W}}
$$

$I R_{\mathrm{det}}=F R \times D E T$

if $t_{b} \leq t \leq t_{e}$

reprod $_{\text {day }}=\frac{\text { reprod } \times W_{t_{b}}}{t_{e}-t_{b}}$

3) Absorption rate $\left(\mathrm{mg} \mathrm{d}^{-1} \mathrm{DW}\right)$ :

$$
\begin{aligned}
& A R_{\text {phy }}=I R_{\text {phy }} \times A E_{\text {phy }} \\
& A R_{\mathrm{det}}=I R_{\mathrm{det}} \times A E_{\mathrm{det}} \\
& A R_{\text {tot }}=\left(A R_{\text {phy }}+A R_{\mathrm{det}}\right) \times F_{\text {pim }}
\end{aligned}
$$$$
\text { either } \text { reprod }_{d a y}=0
$$

6) Scope for Growth $\left(\mathrm{mg} \mathrm{d}^{-1}\right)$ :

with:

$F_{\text {pim }}=m a-m b \times P I M$ if $\mathrm{PIM} \geq 2$

$$
\frac{d W}{d t}=A R_{\text {final }}-R_{\text {tot }}-\text { reprod }_{d a y}
$$

$F_{\text {pim }}=0$ either

As also:

$A R_{\text {max }}=S A R_{\text {max }} \times W^{b 1}$

Finally:

$A R_{\text {final }}=\min \left(A R_{\text {tot }}, A R_{\max }\right)$

W : AFDW of soft body (mg)

PHY: phytoplankton concentration (mg L-1 DW)

4) Respiration rate ( $\left.\mathrm{mg} \mathrm{d}^{-1} \mathrm{DW}\right)$ :

DET: detrital particulate organic matter (mg L ${ }^{-1} \mathrm{DW}$ )

$R M=r a \times(T-r b)^{r c} \times e^{r d \times(T-r b)}$

PIM: particulate inorganic suspended matter

$R A=\operatorname{activ} \times A R_{t o t}$ $\left(\mathrm{mg} \mathrm{L}^{-1}\right)$

$R_{\text {tot }}=(R M+R A) \times W^{b 2}$ 
Table 3: Parameters of the growth model

\begin{tabular}{|c|c|c|c|c|}
\hline Parameter & Comments & Unit & Value & references \\
\hline $\begin{array}{l}\mathrm{fa} \\
\mathrm{fb}\end{array}$ & $\begin{array}{l}\text { parameters of the filtration rate - food } \\
\text { concentration relationship }\end{array}$ & $\begin{array}{l}\mathrm{L} \mathrm{h}^{-1} \\
\mathrm{mg} \mathrm{L}^{-1} \mathrm{MS}\end{array}$ & $\begin{array}{l}2.18 \\
0.1152\end{array}$ & $\begin{array}{l}\text { Converted from } \\
\text { Savina and Pouvreau } \\
\text { (2004) }\end{array}$ \\
\hline $\begin{array}{l}\mathrm{fc} \\
\mathrm{fd} \\
\mathrm{fe} \\
\mathrm{ff} \\
\mathrm{b} 1\end{array}$ & $\begin{array}{l}\text { Parameters of the filtration rate - temperature } \\
\text { relationship }\end{array}$ & $\begin{array}{l}\mathrm{mg} \mathrm{j}^{-1}\left({ }^{\circ} \mathrm{C}\right)^{-1} \mathrm{DW} \\
{ }^{\circ} \mathrm{C} \\
\text { dimensionless } \\
\left({ }^{\circ} \mathrm{C}\right)^{-1} \\
\text { dimensionless }\end{array}$ & $\begin{array}{l}0.000158 \\
2.4876 \\
6.1583 \\
0.5392 \\
2 / 3\end{array}$ & $\begin{array}{l}\text { Calibrated (considering } \\
\text { that the effect of } T^{\circ} \text { in the } \\
\text { GNB range was null) } \\
\text { see the text }\end{array}$ \\
\hline $\mathrm{AE}_{\text {phy }}$ & absorption efficiency for phytoplankton & dimensionless & 0.897 & $\begin{array}{l}\text { Savina and Pouvreau } \\
(2004)\end{array}$ \\
\hline $\mathrm{AE}_{\text {det }}$ & $\begin{array}{l}\text { absorption efficiency for detrital particulate } \\
\text { organic matter }\end{array}$ & dimensionless & 0.41 & calibration \\
\hline $\begin{array}{l}\mathrm{ma} \\
\mathrm{mb}\end{array}$ & $\begin{array}{l}\text { calibrated parameters for total absorption rate } \\
\text { as a function of PIM concentration }\end{array}$ & $\begin{array}{l}\text { dimensionless } \\
\mathrm{L} \mathrm{mg}^{-1}\end{array}$ & $\begin{array}{l}1.157 \\
0.095\end{array}$ & see the text \\
\hline $\mathrm{SAR}_{\max }$ & Maximum standard absorption rate & mg d-1 DW & 13.8 & $\begin{array}{l}\text { Calibrated (maximal } \\
\text { absorption rate } \\
\text { recorded in the GNB) }\end{array}$ \\
\hline ra & & $\mathrm{mg} \mathrm{dj}^{-1}\left({ }^{\circ} \mathrm{C}\right)^{-1} \mathrm{MS}$ & 0.003 & \\
\hline $\begin{array}{l}\mathrm{rb} \\
\mathrm{rc} \\
\mathrm{rd}\end{array}$ & $\begin{array}{l}\text { calibrated parameters for maintenance } \\
\text { respiration rate as a function of temperature }\end{array}$ & $\begin{array}{l}{ }^{\circ} \mathrm{C} \\
\text { dimensionless } \\
\left({ }^{\circ} \mathrm{C}\right)^{-1}\end{array}$ & $\begin{array}{l}0.1 \\
3.88 \\
-0.2\end{array}$ & $\begin{array}{l}\text { Calculated from } \\
\text { available data in } \\
\text { Savina and Pouvreau }\end{array}$ \\
\hline activ & $\begin{array}{l}\text { proportion of absorbed energy respired to } \\
\text { support nutrition activity }\end{array}$ & dimensionless & 0.17 & 2004 \\
\hline b2 & allometric coefficient for catabolism & dimensionless & 0.75 & See the text \\
\hline $\begin{array}{l}t_{b} \\
t_{e}\end{array}$ & limits of the spawning period & julian day & $\begin{array}{l}152 \\
273\end{array}$ & Calculated from \\
\hline $\mathrm{W}_{\text {threshold }}$ & minimum weight for reproduction & 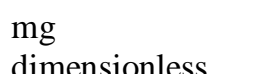 & 200 & \\
\hline $\begin{array}{l}\mathrm{pb} \\
\mathrm{pc} \\
\mathrm{pd}\end{array}$ & $\begin{array}{l}\text { parameters for the weight loss due to } \\
\text { reproduction as a function of soft body } \\
\text { weight }\end{array}$ & $\begin{array}{l}\text { dimensionless } \\
\text { dimensionless } \\
\mathrm{mg}^{-1} \text { PSSC }\end{array}$ & $\begin{array}{l}1 \\
80 \\
-0.01\end{array}$ & calibration \\
\hline
\end{tabular}


Table 4: Conversion factors used to calculate the POM concentrations from chlorophyll concentrations of the cocktail of algae used during ecophysiological experiments; from Brown, 1991.

571

\begin{tabular}{lll}
\hline Species & pg cell $^{-1}$ chl a & pg cell $^{-1} \mathrm{MS}$ \\
\hline Chaetoceros calcitrans & average: 0.485 & average: 31.75 \\
Skeletonema costatum & 0.29 & 269 \\
Isochrisis aff. galbana & 3.83 & 29.7 \\
Tetraselmis chui & 1.535 & 110.15 \\
Average & & \\
\hline
\end{tabular}


577

578

579

580
Table 5: Conversion factors used to calculate the POM concentrations corresponding to the $\mathrm{N}$ and $\mathrm{C}$ concentrations of diatoms and detrital particulate organic matter respectively, given by the biogeochemical model (Hoch, 1998).

\begin{tabular}{lll}
\hline Ratios & Values & References \\
\hline$\mu \mathrm{g}$ chl a / $\mu$ mol phytoplanktonic N & 1 & Aminot et al, 1997 \\
mg C / $\mu$ g phytoplanktonic chl a & 6 & Eppley et al, 1971 \\
mg C / mg dry weight of living organic matter & 0.25 & Le Fèvre Lehoërff et al, 1993 \\
mg C / mg dry weight of detrital matter & 0.38 & Soletchnik et al, 1996 \\
\hline
\end{tabular}


Figures

581

582

583

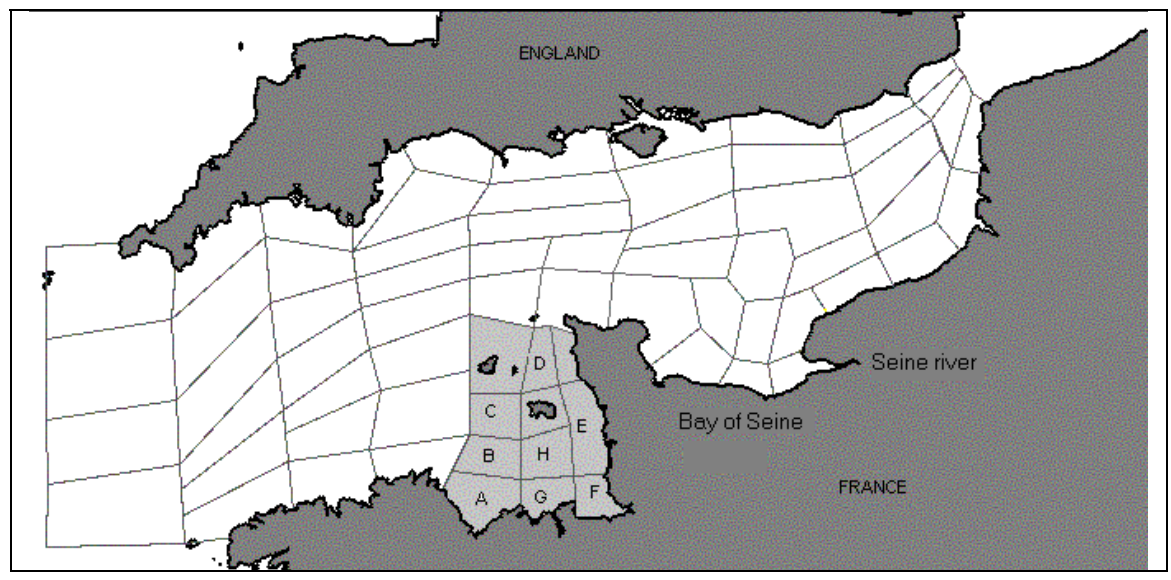

Figure 1: The English Channel and the ecological box model design. The light grey area is the "Golfe Normand-Breton"'(GNB). 


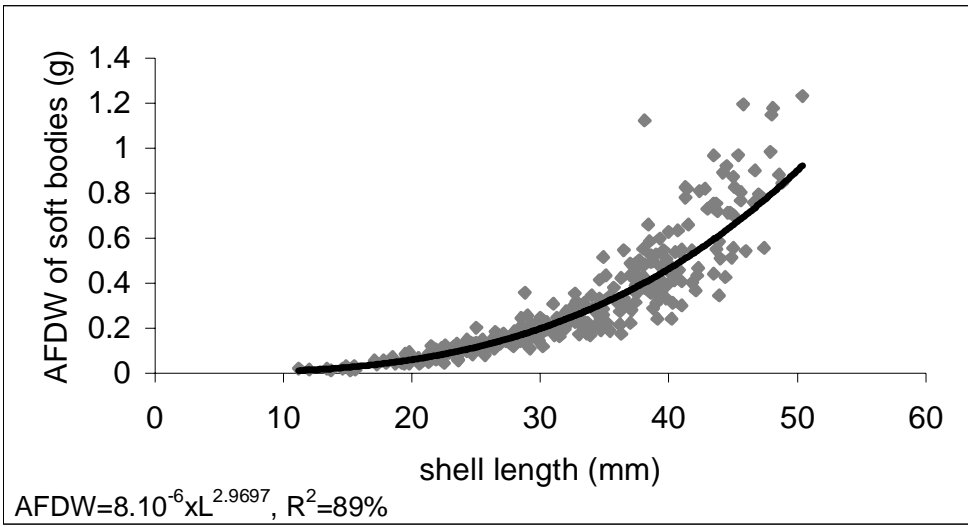




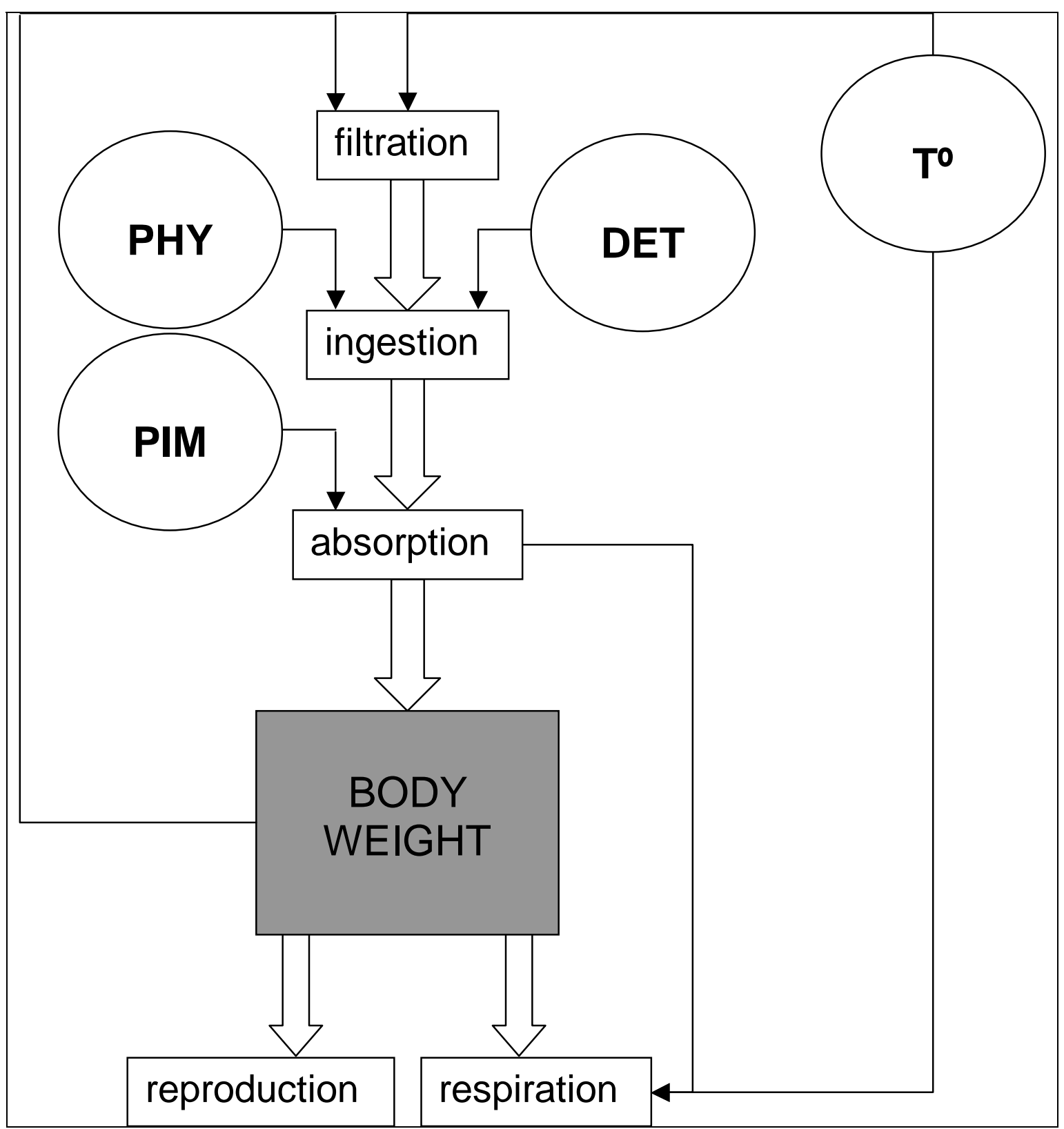

Figure 3: Conceptual diagram of the growth model. Circles represent the environmental variables: phytoplankton (PHY), detrital particulate organic matter (DET) and particulate inorganic matter (PIM) concentrations, and the temperature $\left(T^{\circ}\right)$. White rectangles represent the processes and the grey rectangle corresponds to the state variable. 

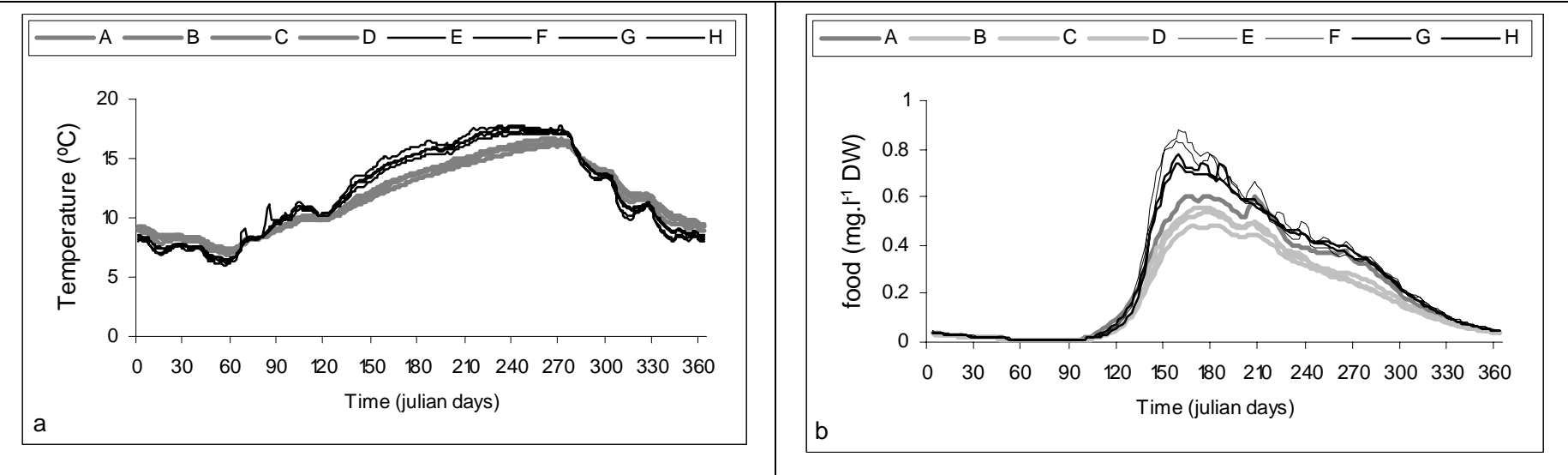

b

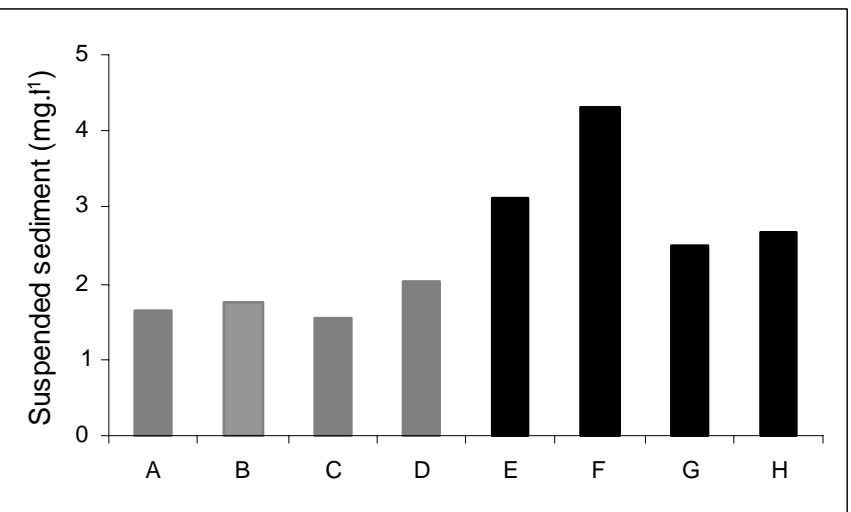

Figure 4: Environmental conditions in different compartments of the GNB; (a) Temperature, (b) Food concentration i.e. diatoms and detrital particulate organic matter and (c) annual average concentration of suspended sediment. The food and temperature datasets are outputs from the physical model, whereas the 

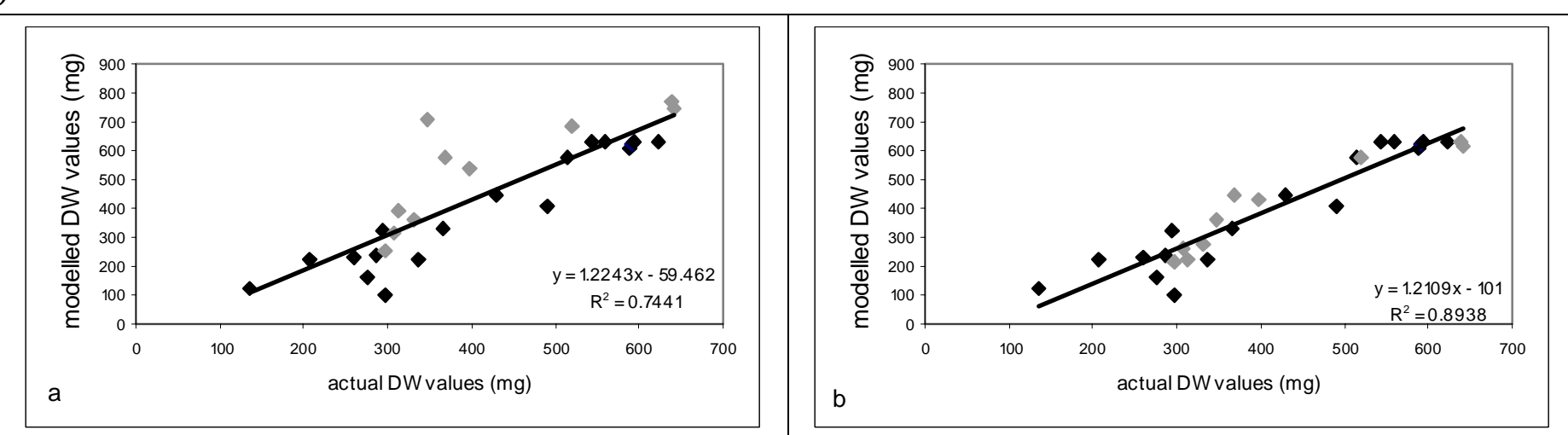

610 Figure 5: Correlation between the average weight measured for each compartment and age class and the corresponding model result (a) for the first version of the model (ie: without suspended sediment influence), and (b) the second version of the model (ie: with suspended sediment influence). In both cases, the grey points correspond to the compartment with significant concentration of suspended sediment. The weight (per age class and compartment) based on less than 5 data were not considered. 
615

616

617

618

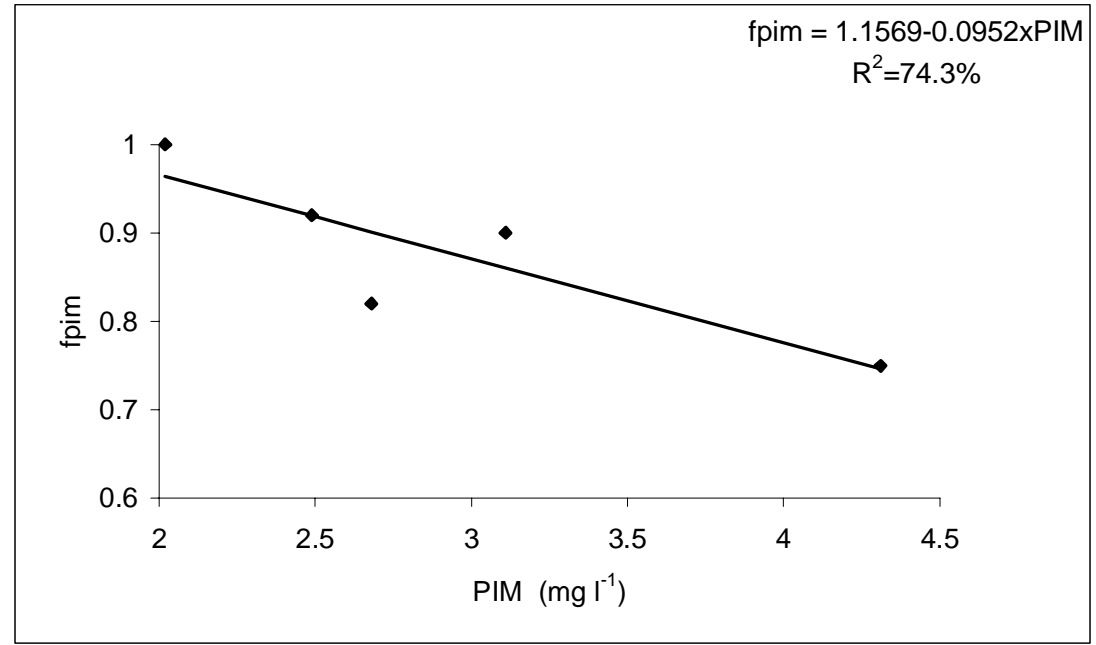

Figure 6: Calibration of the correcting factor of total absorption as a function of suspended sediment concentration. Dots represent the values of fpim calibrated for each compartment, and the line a linear function adjusted to these results, to be used in the second version of the model. 


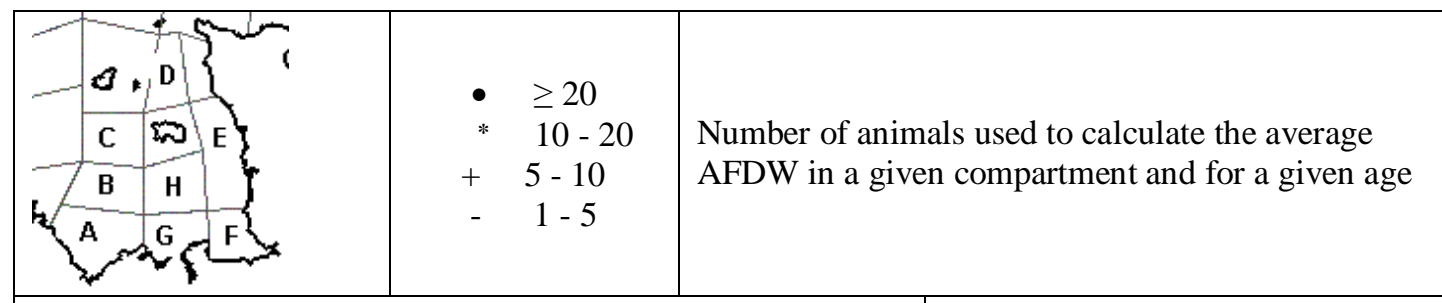
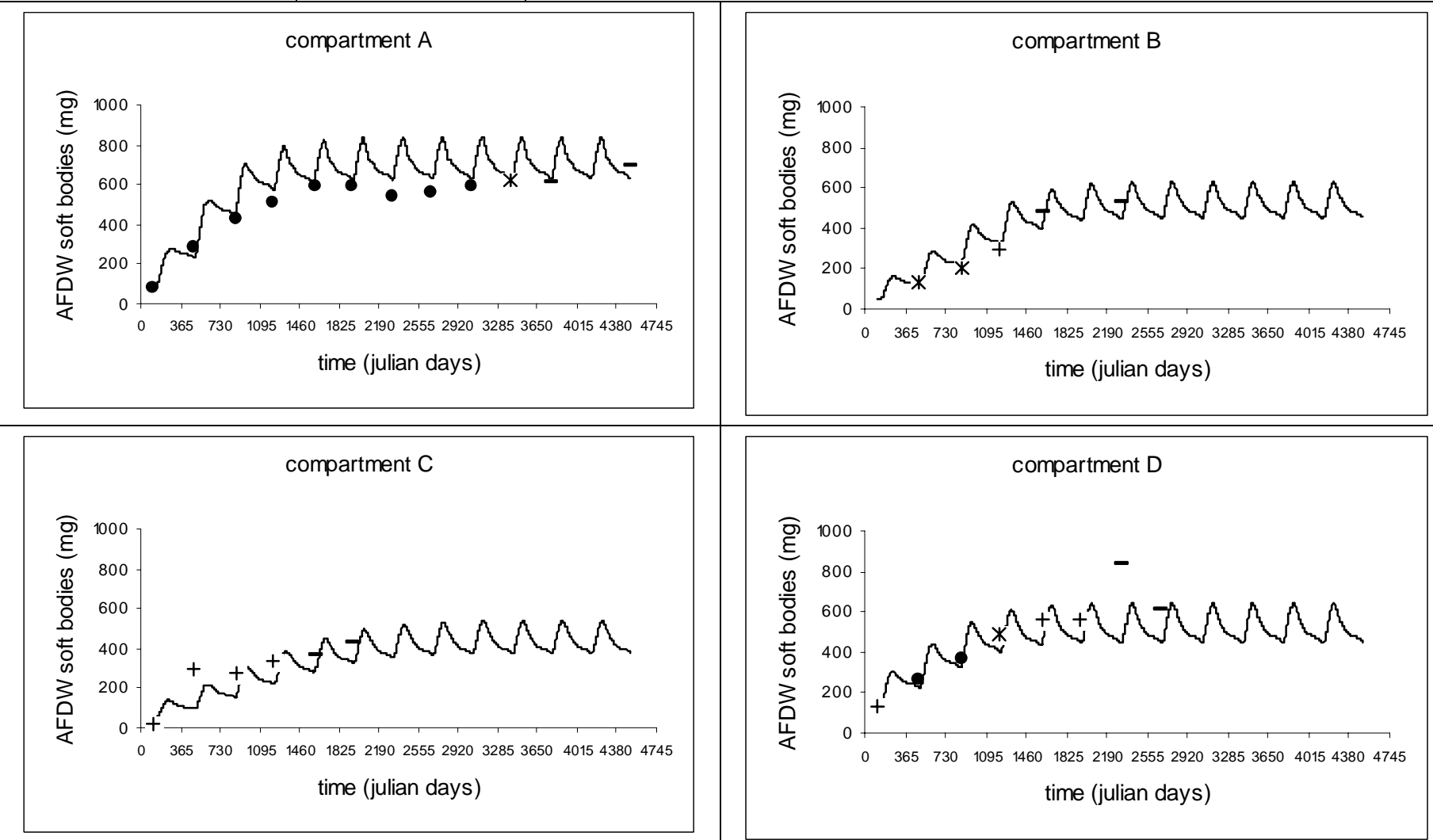

compartment $\mathrm{D}$
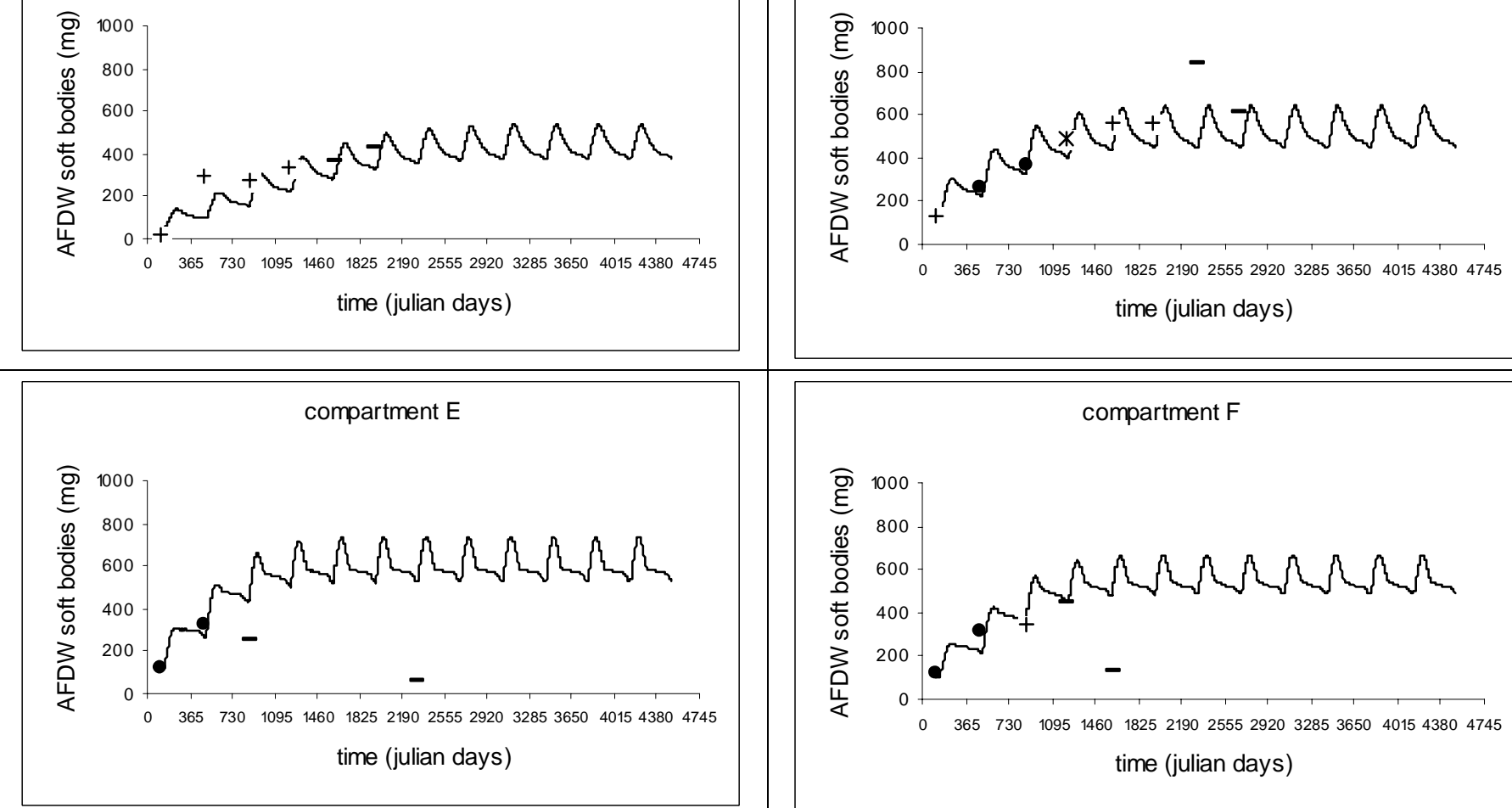
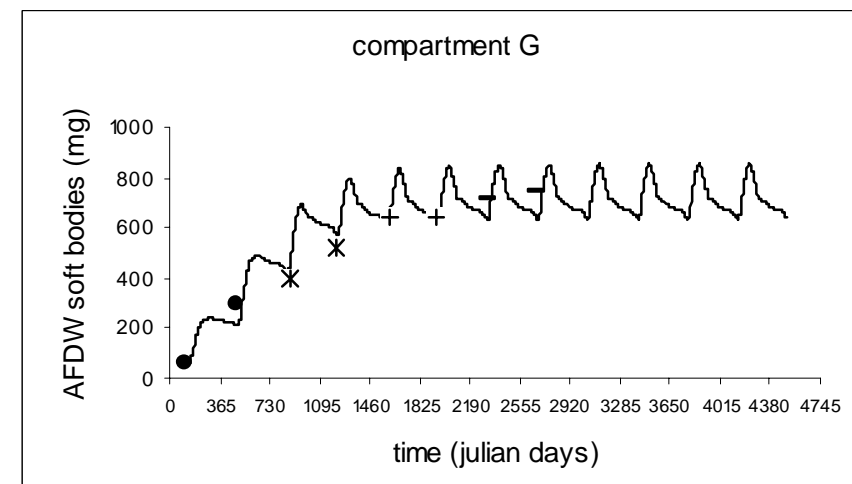
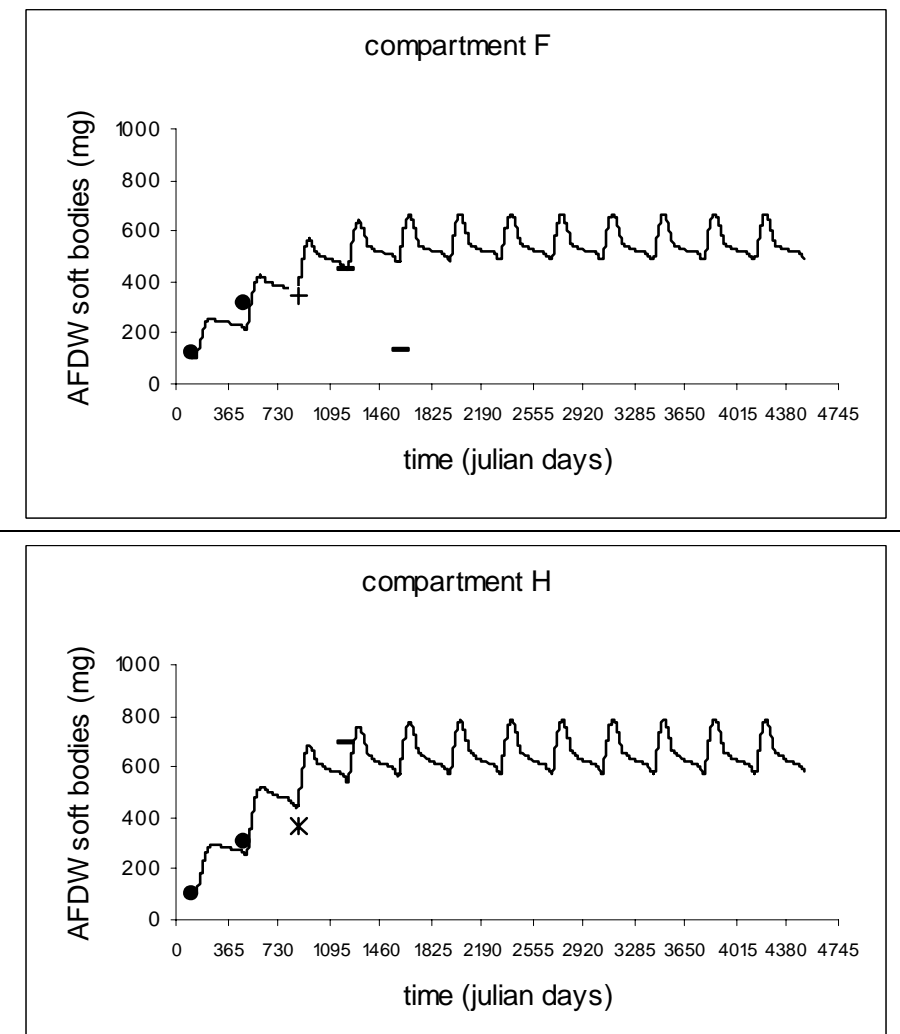


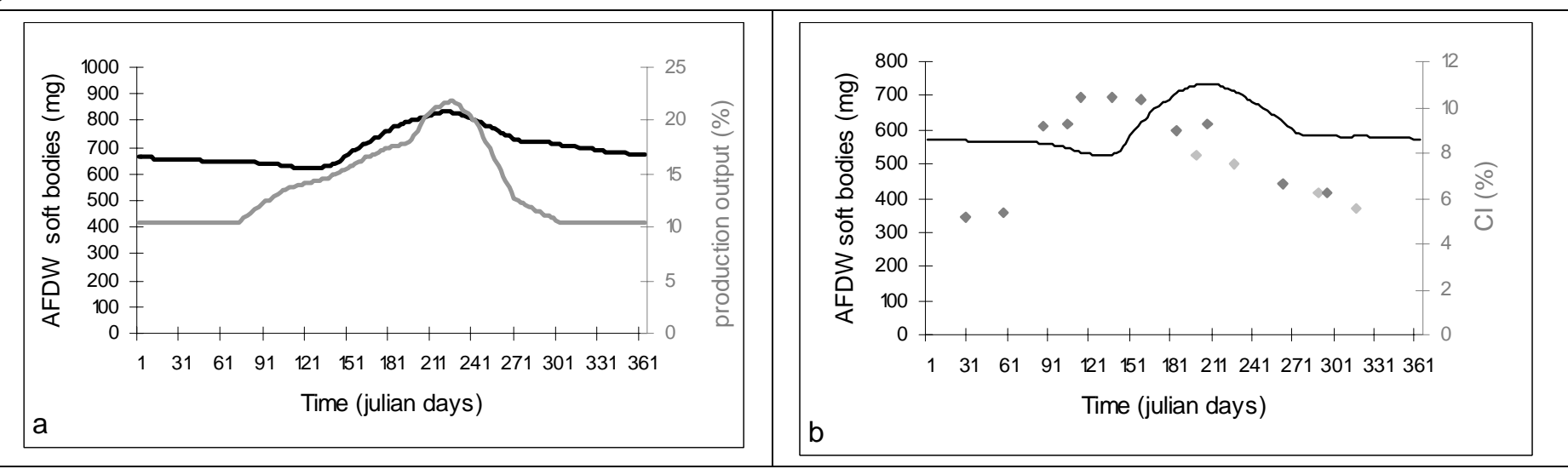

666 Figure 8: Daily time course of 5 years old individual weight over a one year period (black line, a: compartment A; b: compartment E), compared with local values of two weight indices (a: the grey line represents the mean production output of a shellfish factory $\%$; b: the light grey points correspond to the condition index for 1984, and the dark grey points correspond to the condition index for 1985; see the text). 

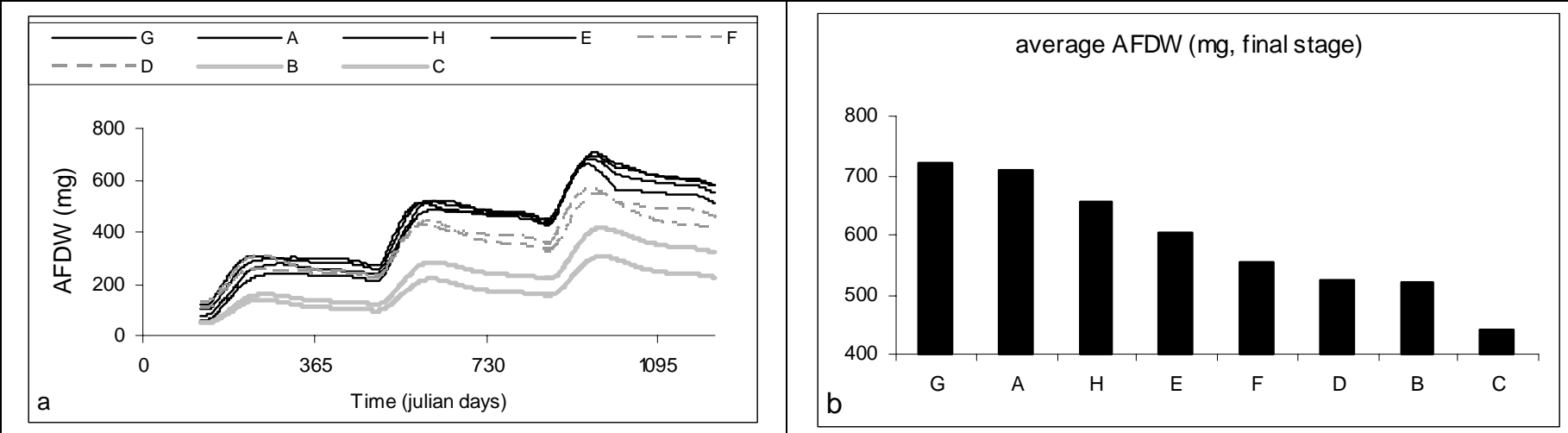

Figure 9: Comparison of the results of the growth model in the different compartments (see figure 1) for the first 3 years of life (1-4 yrs, a) and for the final adult weight (mean of the 9-12 yrs, b). 

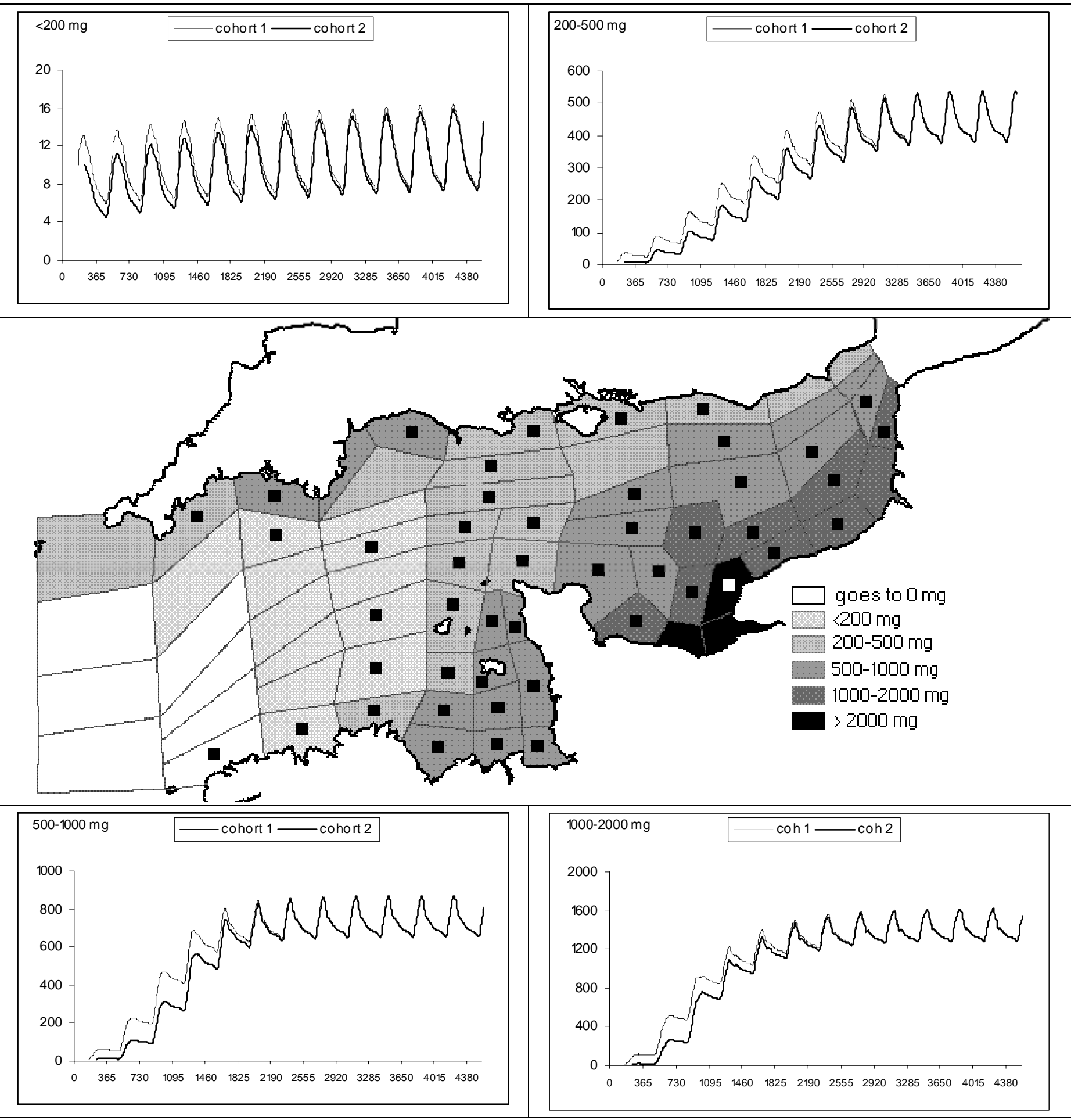

Figure 10: Results of the growth model obtained in the whole English Channel area. Graphics: life course of the individual weight (mg AFDW of soft bodies); time is expressed in julian days. Central map: classification of the different areas of the English Channel into growth categories, on the basis of the asymptotic individual weight. The squares (black or white) show the compartments where $P$. rhomboïdes is present (compilation of Cabioch, Glaçon and Rétière data: Cabioch, pers. comm.) 


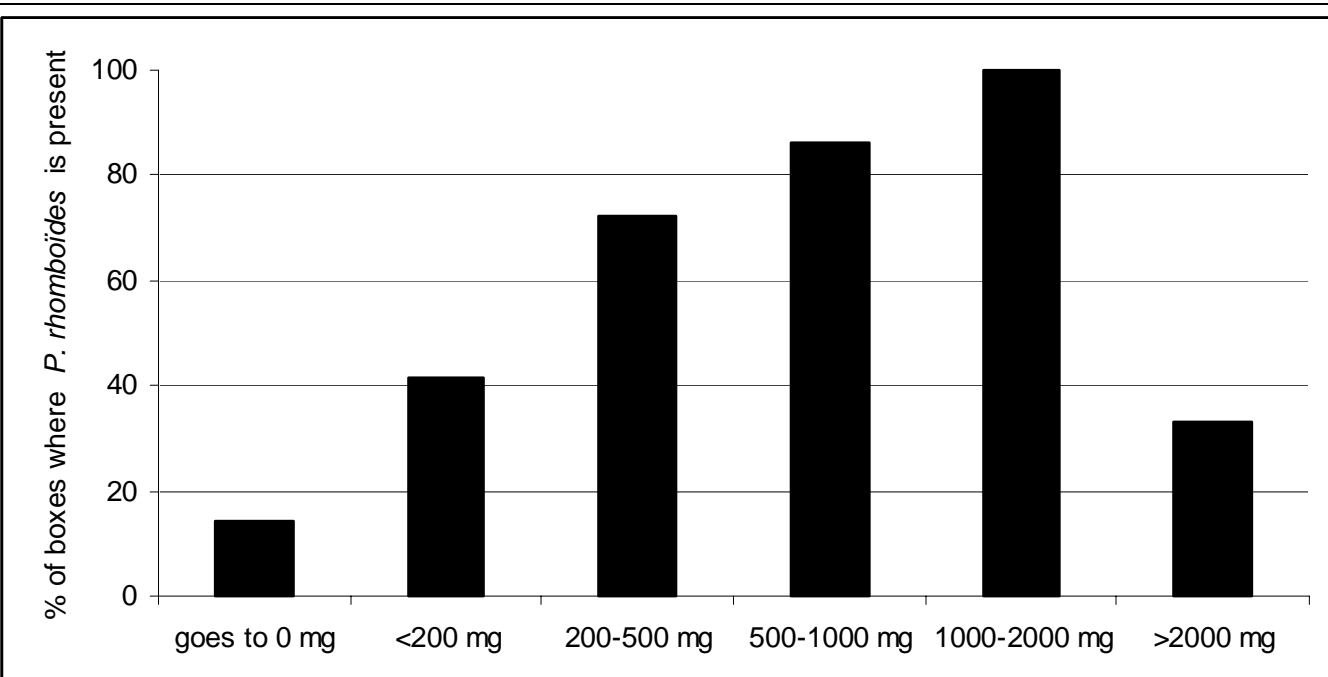

Figure 11: Proportion of boxes where P. rhomboïdes is present for each weight categories identified from the model results (central map of figure 9, asymptotic individual weight). 